Brief Report

\title{
Increased Grain Amino Acid Content in Rice with Earthworm Castings
}

\author{
Min Huang * ${ }^{\mathbb{D}}$, Chunrong Zhao and Yingbin Zou \\ Southern Regional Collaborative Innovation Center of Grain and Oil Crops (CICGO), \\ Hunan Agricultural University, Changsha 410128, China; crzhao5@163.com (C.Z.); ybzou123@163.com (Y.Z.) \\ * Correspondence: mhuang@hunau.edu.cn; Tel.: +86-731-84618758
}

Received: 3 February 2019; Accepted: 12 March 2019; Published: 15 March 2019

Featured Application: Enhancing earthworm activity in the field may be a feasible way to increase grain amino acid content in rice.

\begin{abstract}
Enhancing the nutritional value of rice can improve the health of rice consumers. Grain amino acid content is an important nutritional component. This study was conducted to test the hypothesis that the application of earthworm castings could increase the grain amino acid content in rice. Results showed that total amino acid content in the grain of rice was significantly elevated by applying earthworm castings $\left(17 \mathrm{~kg} \mathrm{~m}^{-2}\right)$, with an average increase of $8 \%$ across four tested rice cultivars. Application of earthworm castings had no significant effect on total nitrogen $(\mathrm{N})$ content but significantly increased the ratio of amino acid to $\mathrm{N}$ (total amino acid content/total $\mathrm{N}$ content) in rice grains. The results of the present study suggest that application of earthworm castings can increase grain amino acid content in rice by improving the efficiency of the $\mathrm{N}$ to amino acid conversion, and highlight that further studies are required to assess the effects of earthworm castings on the amino acid metabolism in rice grains.
\end{abstract}

Keywords: amino acid content; earthworm castings; rice

\section{Introduction}

Rice feeds more than half of the global population [1], and many consumers of rice are among the world's poorest, with diets that are mainly restricted to rice as it is filling, accessible, and affordable [2]. However, rice is deficient in many nutrients [3], and thus malnutrition is common in countries where rice is the main food [4]. Therefore, it is important to enhance the nutritional value of rice to improve the health of rice consumers, especially those living in poverty.

Amino acid content is an important nutritional component on which many rice breeding programs have focused [5]. Grain amino acid content in rice is determined not only by genetic factors but also by environmental factors and management practices [6,7]. Previous studies demonstrated that there is a positive linear relationship between amino acid and nitrogen $(\mathrm{N})$ contents in grains of rice [8], and that amino acid content in the rice grain can be increased by applying $\mathrm{N}$ fertilizer at the heading stage [6].

China is the largest producer and consumer of rice in the world, accounting for about a third of the global rice economy [9]. In the past several decades, the large input of $\mathrm{N}$ fertilizer across wide areas of China has caused considerable environmental costs, including soil acidification, water eutrophication, and enhanced $\mathrm{N}$ deposition [10-12]. Because of these effects, methods other than an artificial increase of $\mathrm{N}$ input are sought to increase rice grain amino acid content.

Earthworm castings, or vermicompost, are a form of fertilizer produced from earthworms as they digest soil organic matter. This excrement is enriched in mineral N [13]. Our recent study showed that application of earthworm castings could improve $\mathrm{N}$ uptake and utilization in rice [14]. The objective 
of the present study was to determine the effects of applying earthworm castings to soil on amino acid and $\mathrm{N}$ contents in the rice grain. We hypothesized that application of earthworm castings may increase grain amino acid content in rice.

\section{Materials and Methods}

A micro-plot field experiment was done in Changsha $\left(28^{\circ} 11^{\prime} \mathrm{N}, 113^{\circ} 04^{\prime} \mathrm{E}\right)$, Hunan Province, China in 2017. The soil in the experimental field was a Fluvisol (FAO taxonomy) with the following chemical properties at the upper $20 \mathrm{~cm}$ layer: $\mathrm{pH} 5.75,34.2 \mathrm{~g}$ organic matter $\mathrm{kg}^{-1}, 81.6 \mathrm{mg}$ available $\mathrm{N} \mathrm{kg}^{-1}, 34.4 \mathrm{mg}$ available $\mathrm{P} \mathrm{kg}^{-1}$, and $56.7 \mathrm{mg}$ available $\mathrm{K} \mathrm{kg}^{-1}$.

Thirty-two bottomless plastic boxes (length $\times$ width $\times$ height $=40 \mathrm{~cm} \times 40 \mathrm{~cm} \times 30 \mathrm{~cm}$ ) were pushed into the soil of the experimental field to a depth of $20 \mathrm{~cm}$ to establish micro-plots. Four rice cultivars (Huanghuazhan, Liangyoupeijiu, Longliangyou 97, and Xiangliangyou 396) were grown and each micro-plot was treated with either earthworm castings $\left(17 \mathrm{~kg} \mathrm{~m}^{-2}, \mathrm{EC} 17\right)$ or no castings $\left(0 \mathrm{~kg} \mathrm{~m}^{-2}, \mathrm{EC} 0\right)$. The level of earthworm castings for EC17 was chosen according to the product of duration of oilseed rape-growing season (218 days) and daily production rate of earthworm castings $\left(78 \mathrm{~g} \mathrm{~m}^{-2}\right.$ day $\left.^{-1}\right)$ in a no-tillage rice-oilseed rape rotation field in Nanxian $\left(29^{\circ} 21^{\prime} \mathrm{N}, 112^{\circ} 25^{\prime} \mathrm{E}\right)$, Hunan Province in 2015. The daily production rate of earthworm castings was obtained from an investigation conducted on 10 randomly selected $1-\mathrm{m}^{2}$ areas in the field on the first day after oilseed rape harvest. The earthworm castings ( $\mathrm{pH} 7.89,61.4 \mathrm{~g}$ organic matter kg-1, $128 \mathrm{mg}$ available $\mathrm{N} \mathrm{kg}^{-1}, 44.2 \mathrm{mg}$ available $\mathrm{P} \mathrm{kg}^{-1}$, and $254 \mathrm{mg}$ available $\mathrm{K} \mathrm{kg}^{-1}$ ) used in the experiment were collected from several no-tillage rice-oilseed rape rotation fields in Nanxian after oilseed rape harvest in 2016. The micro-plots were arranged in a split-plot design with four replicates, using the level of earthworm castings as the main plots and cultivars as the subplots.

Rice seeds were pre-germinated and then sown in a seedbed on 10 May. Rice seedlings were transplanted on 5 June with one seedling per hill and four hills per micro-plot. Earthworm castings were applied and incorporated in the upper $20 \mathrm{~cm}$ of the soil on the day before transplanting. Urea was split in three applications: $6.0 \mathrm{~g} \mathrm{~N} \mathrm{~m}^{-2}$ at 1 day before transplanting (basal), $3.6 \mathrm{~g} \mathrm{~N} \mathrm{~m}^{-2}$ at 7 days after transplanting, and $2.4 \mathrm{~g} \mathrm{~N} \mathrm{~m}^{-2}$ at panicle initiation. Superphosphate was applied as basal at a rate of $4.8 \mathrm{~g} \mathrm{P}_{2} \mathrm{O}_{5} \mathrm{~m}^{-2}$. Potassium chloride $\left(8.4 \mathrm{~g} \mathrm{~K}_{2} \mathrm{O} \mathrm{m}^{-2}\right)$ was split equally in two applications: one at basal and the other at panicle initiation. The micro-plots were flooded with a water depth of about $5 \mathrm{~cm}$ until 7 days before maturity. Agrochemicals were used to control diseases, insects, and weeds.

At maturity, rice grains were sampled from each micro-plot. The sampled grains were oven-dried at $70{ }^{\circ} \mathrm{C}$ to a constant weight and then hulled, ground, and sieved (100 mesh). About $1.0 \mathrm{~g}$ of the sieved sample was weighed, hydrolyzed, and derivatized to determine total amino acid content with high-performance liquid chromatography method [15]. Approximately $0.5 \mathrm{~g}$ of the sieved sample was digested by $\mathrm{H}_{2} \mathrm{SO}_{4}-\mathrm{H}_{2} \mathrm{O}_{2}$ method to determine the total $\mathrm{N}$ content. The $\mathrm{N}$ analysis was carried out using a segmented flow analyzer (SAN Plus, Skalar Inc., Breda, The Netherlands). The ratio of amino acid to $\mathrm{N}$ (total amino acid content/total $\mathrm{N}$ content) was calculated.

Data analysis including analysis of variance and linear regression analysis was performed using Statistix 8.0 (Analytical Software, Tallahassee, FL, USA).

\section{Results and Discussion}

Total amino acid content in rice grains was significantly influenced by both the level of earthworm castings and cultivar (Table 1). There was no significant interaction effect between the level of earthworm castings and cultivar on total amino acid content in the grain of rice. Averaged across the four cultivars, total amino acid content in the grain was 8\% higher under EC17 than under EC0. Huanghuazhan had the highest total amino acid content in grains, more than $10 \%$ higher than that of the other three cultivars. 
Table 1. Effects of earthworm casting application on total amino acid and nitrogen $(\mathrm{N})$ content and on ratio of amino acid to $\mathrm{N}$ in grains of four rice cultivars.

\begin{tabular}{|c|c|c|c|c|}
\hline $\begin{array}{l}\text { Earthworm } \\
\text { Castings }\end{array}$ & Cultivar & $\begin{array}{l}\text { Total Amino Acid } \\
\left(\mathrm{mg} \mathrm{g}^{-1}\right)\end{array}$ & $\begin{array}{c}\text { Total N } \\
\left(\mathrm{mg} \mathrm{g}^{-1}\right)\end{array}$ & $\begin{array}{l}\text { Ratio of Amino } \\
\text { Acid to } \mathbf{N}\end{array}$ \\
\hline \multirow[t]{5}{*}{ EC0 } & Huanghuazhan & $67.8(3.52)$ & $15.3(0.28)$ & $4.44(0.232)$ \\
\hline & Liangyoupeijiu & $60.8(2.40)$ & $13.8(0.05)$ & $4.42(0.179)$ \\
\hline & Longliangyou 97 & $56.7(3.63)$ & $13.4(0.22)$ & $4.22(0.288)$ \\
\hline & Xiangliangyou 396 & $58.8(3.40)$ & $13.7(0.07)$ & $4.30(0.250)$ \\
\hline & Mean & $61.0(1.82)$ & $14.1(0.20)$ & $4.35(0.110)$ \\
\hline \multirow[t]{5}{*}{ EC17 } & Huanghuazhan & $73.0(3.61)$ & $15.3(0.07)$ & $4.78(0.218)$ \\
\hline & Liangyoupeijiu & $62.9(2.49)$ & $13.6(0.09)$ & $4.63(0.198)$ \\
\hline & Longliangyou 97 & $64.4(1.67)$ & $13.5(0.01)$ & $4.79(0.125)$ \\
\hline & Xiangliangyou 396 & $62.0(2.62)$ & $13.2(0.11)$ & $4.71(0.183)$ \\
\hline & Mean & $65.6(1.65)$ & $13.9(0.22)$ & $4.73(0.084)$ \\
\hline \multicolumn{5}{|c|}{ Analysis of variance ( $F$-value) } \\
\hline \multicolumn{2}{|c|}{ Earthworm castings } & $4.65 *$ & $2.20 \mathrm{~ns}$ & $6.29 *$ \\
\hline \multicolumn{2}{|c|}{ Cultivar } & $5.03 * *$ & $70.44^{* *}$ & $0.11 \mathrm{~ns}$ \\
\hline \multicolumn{2}{|c|}{ Earthworm castings $\times$ Cultivar } & $0.34 \mathrm{~ns}$ & $1.36 \mathrm{~ns}$ & $0.24 \mathrm{~ns}$ \\
\hline
\end{tabular}

$\mathrm{N}$ is a principal constitute element of amino acids. It is generally considered that amino acid content is positively linearly related to $\mathrm{N}$ content in the rice grain [8]. Some findings of this study are consistent with those of previous studies: Huanghuazhan, the cultivar with highest grain amino acid content, also had higher grain $\mathrm{N}$ content than the other three cultivars (Table 1). However, unexpectedly, no significant difference was recorded in the grain N content between the EC17 and EC0 treatments. Thus, increasing the grain $\mathrm{N}$ content was not the mechanism for the positive impact of applying earthworm castings on amino acid content in rice grains. Our study also showed that the EC17 treatment had a significantly higher ratio of amino acid to N than EC0 (Table 1). This result suggests that the increased grain amino acid content in rice induced by applying earthworm castings might be mostly attributable to the improved efficiency of converting $\mathrm{N}$ to amino acid. This could be further supported and informed by that the linear regression between grain amino acid and $\mathrm{N}$ contents was different under EC17 and EC0 (Figure 1). These results suggest that further investigations are required to determine the effects of earthworm castings on the metabolism of amino acid in rice grains.

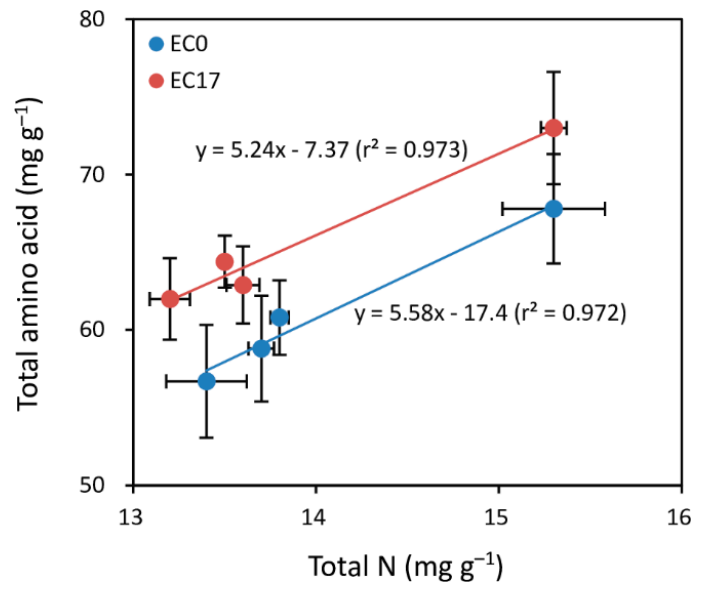

Figure 1. Linear regression between total amino acid and $\mathrm{N}$ contents in grains of four rice cultivars under two levels of earthworm castings. EC0 and EC17 represent 0 and $17 \mathrm{~kg}$ earthworm castings m$^{-2}$, respectively. Each data point is the mean for one cultivar under one level of earthworm castings. Error bars are $\mathrm{SE}(n=4)$. 
Application of earthworm castings can affect plant metabolism including protein synthetic activity $[16,17]$. In this regard, it is well documented that the castings and body secretions of earthworms contain a certain amount of plant hormones and hormone-like substances [18-20]. Earthworms can also enhance microbial biomass and activity due to their castings and mucus, and the byproducts of this microbial activity include plant hormones such as abscisic acids, auxins, cytokinins, ethylene, and gibberellins [21]. Although there is limited information available on the influences of plant hormones or plant hormone-like substances included in earthworm castings on amino acid metabolism in the rice crop, some relevant reports have been documented in other crops. For example, Muscolo et al. [22] found that earthworm-worked humic substances had an auxin-like effect on nitrogen metabolism in wild carrot, and Singh et al. [23] observed that gibberellic acid-like activity of vermicompost leachate resulted in an increase in amino acids in the common bean. Further study is required to determine if similar effects of plant hormones and hormone-like substances in earthworm castings are observed on amino acid metabolism in rice grains.

Application of earthworm castings has the potential for increasing amino acid content in rice grains, although the practicality of any approach must be taken into account. High labor costs are the key factor limiting the adoption of organic manures. In this study, the tested earthworm castings were not specially produced but were collected from no-tillage rice-oilseed rape rotation fields, where earthworms are known to be abundant (pers. obs.). Reduced or absent soil tillage in these fields can provide earthworms with an undisturbed biotope and hence may be favorable to increasing their populations, while oilseed rape plants can provide abundant food for earthworms by producing large volumes of residues. In addition, our previous study documented that adoption of no-tillage rice-oilseed rape cropping systems can maintain crop yields while saving labor [24]. Therefore, development of similar no-tillage systems may be an indirect but feasible way to increase grain amino acid content in rice by increasing earthworm activity.

Author Contributions: Conceptualization, M.H. and Y.Z.; Investigation, C.Z.; Writing, M.H.; Funding Acquisition, M.H. and Y.Z.

Funding: This research was funded by [the National Key R\&D Program of China] grant number [2016YFD0300509] and [the Earmarked Fund for China Agriculture Research System] grant number [CARS-01].

Conflicts of Interest: The authors declare no conflict of interest.

\section{References}

1. Muthayya, S.; Sugimoto, J.D.; Montgomery, S.; Maberly, G.F. An overview of global rice production, supply, trade, and consumption. Ann. N. Y. Acad. Sci. 2014, 1324, 7-14. [CrossRef] [PubMed]

2. Bhullar, N.K.; Grussem, W. Nutritional enhancement of rice for human health: The contribution of biotechnology. Biotechnol. Adv. 2013, 31, 50-57. [CrossRef]

3. Birla, D.S.; Malik, K.; Sainger, M.; Chaudhary, D.; Jaiwal, R.; Jaiwal, P.K. Progress and challenges in improving nutritional quality of rice (Oryza sativa L.). Crit. Rev. Food Sci. Nutr. 2017, 57, 2455-2481. [CrossRef] [PubMed]

4. Muthayya, S.; Rah, J.H.; Sugimoto, J.D.; Roos, F.F.; Kraemer, K.; Black, R.E. The global hidden hunger indices and maps: An advocacy tool for action. PLoS ONE 2013, 8, e67860. [CrossRef]

5. Wang, L.; Zhong, M.; Li, X.; Yuan, D.; Xu, Y.; Liu, H.; He, Y.; Luo, L.; Zhang, Q. The QTL controlling amino acid content in grains of rice (Oryza sativa) are co-localized with regions involved in the amino acid metabolism pathway. Mol. Breed. 2008, 21, 127-137. [CrossRef]

6. Dou, Z.; Tang, S.; Li, G.; Liu, Z.; Ding, C.; Chen, L.; Wang, S.; Ding, Y. Application of nitrogen fertilizer at heading stage improves rice quality under elevated temperature during grain-filling stage. Crop Sci. 2017, 57, 2183-2192. [CrossRef]

7. Liu, Q.; Wu, X.; Ma, J.; Li, T.; Zhou, X.; Guo, T. Effects of high air temperature on rice grain quality and yield under field condition. Agron. J. 2013, 105, 446-454. [CrossRef]

8. Mossé, J.; Huet, J.C.; Baudet, J. The amino acid composition of rice grain as a function of nitrogen content as compared with other cereals: A reappraisal of rice chemical scores. J. Cereal Sci. 1988, 8, 165-175. [CrossRef] 
9. World Rice Statistics Database. Available online: http://ricestat.irri.org:8080/wrsv3 (accessed on 31 January 2019).

10. Guo, J.H.; Liu, X.J.; Zhang, Y.; Shen, J.L.; Han, W.X.; Zhang, W.F.; Christie, P.; Goulding, K.W.T.; Vitousek, P.M.; Zhang, F.S. Significant acidification in major Chinese croplands. Science 2010, 327, 1008-1010. [CrossRef] [PubMed]

11. Le, C.; Zha, Y.; Li, Y.; Sun, D.; Lu, H.; Yin, B. Eutrophication of lake waters in China: Cost, causes, and control. Environ. Manag. 2010, 45, 662-668. [CrossRef] [PubMed]

12. Liu, X.; Zhang, Y.; Han, W.; Tang, A.; Shen, J.; Cui, Z.; Vitousek, P.; Erisman, J.W.; Goulding, K.; Christie, P.; et al. Enhanced nitrogen deposition over China. Nature 2013, 494, 459-462. [CrossRef]

13. Parkin, T.B.; Berry, E.C. Nitrogen transformations associated with earthworm casts. Soil Biol. Biochem. 1994, 26, 1233-1238. [CrossRef]

14. Huang, M.; Zhou, X.; Xie, X.; Zhao, C.; Chen, J.; Cao, F.; Zou, Y. Rice yield and the fate of fertilizer nitrogen as affected by addition of earthworm casts collected from oilseed rape fields: A pot experiment. PLoS ONE 2016, 11, e0167152. [CrossRef]

15. Cohen, S.A.; De Antonis, K.M. Applications of amino acid derivation with 6-aminoquinolyl-Nhydroxysuccinimidyl carbamate: Analysis of feed grains, intravenous solutions and glycoproteins. J. Chromatogr. A 1994, 661, 25-34. [CrossRef]

16. Galli, E.; Tomati, U.; Grappelli, A.; Di Lena, G. Effect of earthworm casts on protein synthesis in Agaricus bisporus. Biol. Fertil. Soils 1990, 9, 290-291. [CrossRef]

17. Tomati, U.; Galli, E.; Grappelli, A.; Di Lena, G. Effect of earthworm casts on protein synthesis in radish (Raphanus sativum) and lettuce (Lactuga sativa) seedlings. Biol. Fertil. Soils 1990, 9, 288-289. [CrossRef]

18. Atiyeh, R.M.; Lee, S.; Edvards, C.A.; Arancon, N.Q.; Metzger, J.D. The influence of humic acids derived from earthworm-processed organic wastes on plant growth. Bioresour. Technol. 2002, 84, 7-14. [CrossRef]

19. Krishnamoorthy, R.V.; Vajranabhaian, S.N. Biological activity of earthworm cats. An assessment of plant growth promoter or levels in the casts. Proc. Indian Acad. Sci. (Anim. Sci.) 1986, 95, 341-351. [CrossRef]

20. Suthar, S. Evidence of plant hormone like substances in vermiwash: An ecologically safe option of synthetic chemicals for sustainable farming. Ecol. Eng. 2010, 36, 1089-1092. [CrossRef]

21. Xu, C.; Mou, B. Vermicompost affects soil properties and spinach growth, physiology, and nutritional value. HortScience 2016, 51, 847-855. [CrossRef]

22. Muscolo, A.; Bovalo, F.; Gionfriddo, F.; Nardi, S. Earthworm humic matter produces auxin like effects on Daucus carota cell growth and nitrogen metabolism. Soil Biol. Biochem. 1999, 31, 1303-1313. [CrossRef]

23. Singh, S.; Kulkarni, M.G.; Staden, J.V. Biochemical changes associated with gibberellic acid-like activity of smoke-water, karrikinolide and vermicompost leachate during seedling development of Phaseolus vulgaris L. Seed Sci. Res. 2014, 24, 63-70. [CrossRef]

24. Huang, M.; Zou, Y.; Feng, Y.; Cheng, Z.; Mo, Y.; Ibrahim, M.; Xia, B.; Jiang, P. No-tillage direct seeding for super hybrid rice production in rice-oilseed rape cropping system. Eur. J. Agron. 2011, 34, 278-286. [CrossRef]

(C) 2019 by the authors. Licensee MDPI, Basel, Switzerland. This article is an open access article distributed under the terms and conditions of the Creative Commons Attribution (CC BY) license (http://creativecommons.org/licenses/by/4.0/). 